This item was submitted to Loughborough's Research Repository by the author.

Items in Figshare are protected by copyright, with all rights reserved, unless otherwise indicated.

\title{
Response of benthic cave invertebrates to organic pollution events
}

PLEASE CITE THE PUBLISHED VERSION

http://dx.doi.org/10.1002/aqc.933

PUBLISHER

(c) John Wiley \& Sons

VERSION

SMUR (Submitted Manuscript Under Review)

LICENCE

CC BY-NC-ND 4.0

REPOSITORY RECORD

Wood, Paul J., J. Gunn, and S.D. Rundle. 2019. "Response of Benthic Cave Invertebrates to Organic Pollution Events". figshare. https://hdl.handle.net/2134/13019. 
This item was submitted to Loughborough's Institutional Repository (https://dspace.lboro.ac.uk/) by the author and is made available under the following Creative Commons Licence conditions.

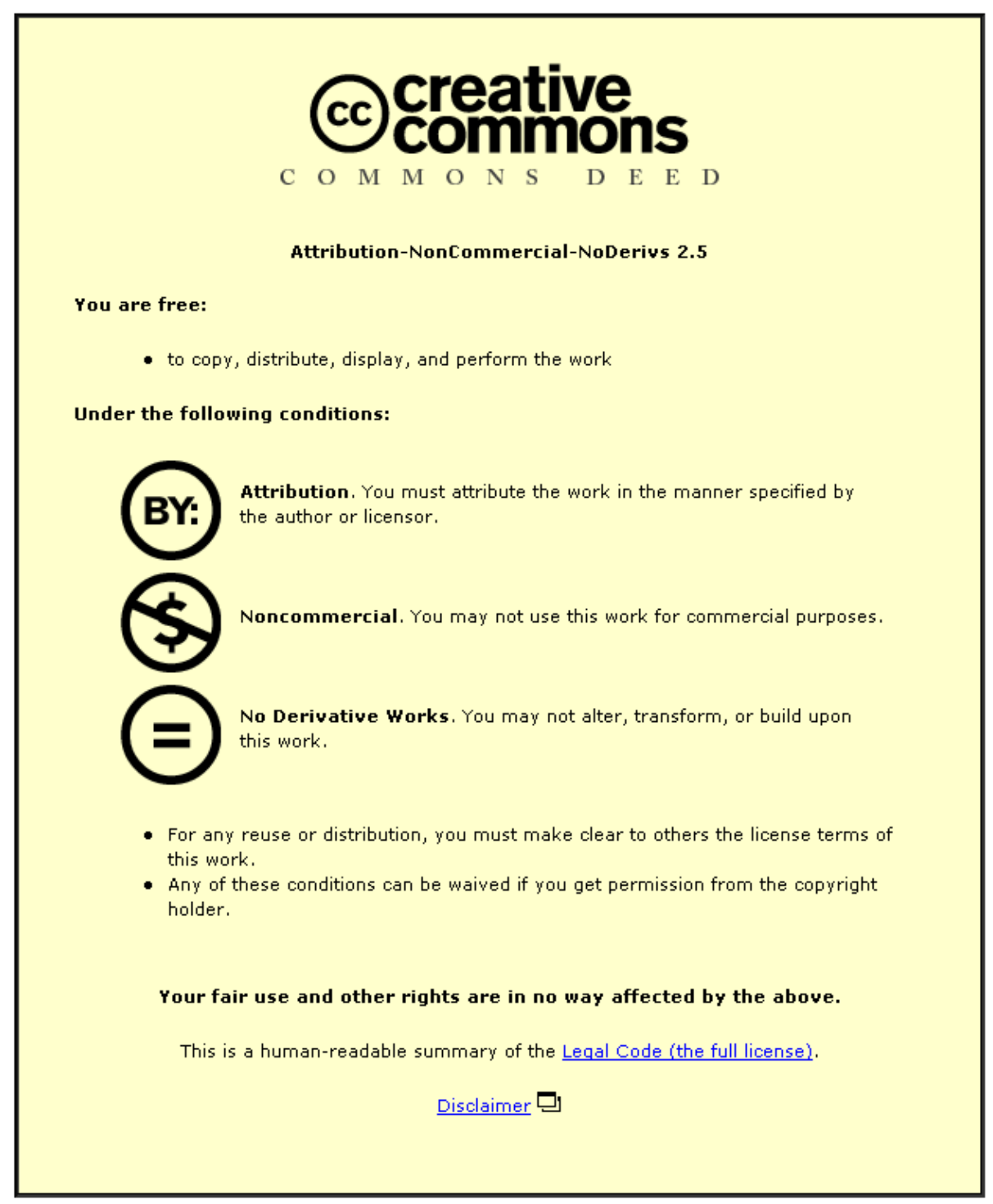

For the full text of this licence, please go to: http://creativecommons.org/licenses/by-nc-nd/2.5/ 
3

WoOD, P.J. ${ }^{1 *}$, GunN, J. ${ }^{2}$ and RundLE, S.D. ${ }^{3}$

5

1. Department of Geography, Loughborough University, Loughborough, Leicestershire, LE11 3TU, United Kingdom.

8

2. Limestone Research Group, School of Geography, Earth and Environmental Sciences, University of Birmingham, Edgbaston, Birmingham,B15 2TT, United Kingdom.

3. School of Biological Sciences, University of Plymouth, Drake Circus, Plymouth, PL4 8AA, United Kingdom.

\section{Corresponding Author*}

15 Dr P.J. Wood

16 Department of Geography

17 Loughborough University

18 Loughborough

19 Leicestershire

20 LE11 3TU

21 United Kingdom

23 Email:- p.j.wood@lboro.ac.uk

24 Tel:- 00 (44) +1509 223012

25 Fax:- $00(44)+1509223930$

26 
1. Even though the fragility and vulnerability of subterranean ecosystems (caves, groundwater and hyporheic habitats) is widely acknowledged, the impacts of anthropogenic disturbances have been poorly quantified when compared to surface waters. In particular, limited data exist regarding the impact of organic pollution upon aquatic cave invertebrate communities.

2. The Peak-Speedwell Cavern system (Derbyshire, UK) was affected by two organic pollution events, during a 7-year study (1997-2003), originating from the same source in the surface catchment but resulting in markedly different ecological responses. The first event led to the elimination of most taxa from affected sites while the second resulted in an increase in abundance of organisms within the cave associated with the increased availability of trophic resources. The second event also coincided with the invasion of the stygophilic amphipod, Gammarus pulex, at a site where it had not previously been recorded.

3. Recovery of the invertebrate community following both organic pollution events occurred within 12-months. Recolonisation of the affected sites was facilitated by annual flooding of the cave and by the presence of refugia on unaffected subterranean tributaries.

4. The data highlight the problems associated with the conservation and management of subterranean ecosystems where impacts in distant surface catchments may have unseen repercussions for the subterranean environment. Aquatic subterranean habitats are not widely monitored and the impacts of pollution/disturbance may not be detected in surface waters for some time, if at all, due to dilution effects. Caves supporting obligate subterreanean organisms (stygobites) are particularly vulnerable to these pressures and require clear management strategies to protect both the subterranean and surface catchments which support them. 
Key Words:- subterranean ecosystem; disturbance; recovery; point source pollution; invertebrates.

\section{Introduction}

The dark zones of caves are naturally typified by low organismal abundance and diversity (Holsinger, 1988; Jasinska et al., 1996; Culver and Sket, 2000), and due to the relatively constant abiotic conditions, their biological communities are widely considered to be more stable compared with those in epigean systems (Culver, 1985; Simon et al., 2003). In the absence of light and primary producers, cave habitats are largely oligotrophic, relying almost exclusively on dissolved or particulate organic matter originating in surface (epigean) habitats (Poulson and Lavoie, 2000; Simon et al., 2003). Hence, it is highly likely that changes in landuse and/or management practices within surface epigean catchments may result in significant changes to the trophic dynamics of subterranean (hypogean) food webs (Poulson and Lavoie, 2000; Hancock et al., 2005). Consequently, aquatic subterranean habitats (hyporheic zone, groundwater and wet caves) are considered to be vulnerable to anthropogenic activities (Sket, 1999; Gunn et al., 2000; van Beynen and Townsend, 2005; Boulton, 2005), yet our understanding of the impacts of such activities upon subterranean ecosystems is much more limited compared with epigean waterbodies (Elliott, 2000; Hancock et al., 2005).

Although there has been some recent increase in interest regarding the impact of disturbances upon biological communities within groundwater aquifers (e.g., Danielopol et al., 2003; Hancock, 2002), research exploring the influence of disturbances upon cave ecosystems has been limited despite wide recognition of their high conservation/biodiversity value (Culver and Sket, 2000). Anthropogenic disturbances and modifications of cave ecosystems associated with heavy metals (Graening and Brown, 2003), faecal bacteria (Green et al., 1990; Simon and Buikema, 1997; Graening and Brown, 2003) and waste disposal (Halliday, 2003) 
81 have been reported. However, the response of cave communities and individual species to

82 organic pollution remains poorly quantified. This paucity of information reflects the absence

83 of pre-disturbance baseline data and/or absence of adjacent control sites which could be used

84 to determine the nature and magnitude of impacts. Those studies that have documented the

85 response of cave invertebrate communities and individual species to organic enrichment and

86 pollution show that responses are variable (Table 1). Significant changes to the structure of

87 cave benthic invertebrate communities, particularly reductions in abundance or exclusion of

88 obligate subterranean aquatic fauna (stygobites) as a result of organic pollution have been

89 reported (Culver et al., 1992, Simon and Builkema, 1997, Graening and Brown, 2003).

90 However, in some instances there have been increases in the abundance of obligate

91 subterranean (hypogean/stygobitic) fauna and/or an increase in species richness of

92 epigean/stygophilic faunal populations within caves, particularly when trophic resource

93 availability is enhanced (Holsinger, 1966, Sket, 1977, Simon and Builkema, 1997, Graening

94 and Brown, 2003). It has even been suggested that mild organic enrichment may be beneficial

95 to stygobitic populations under some circumstances, provided that highly competitive

96 stygophiles, epigean taxa able to complete their life-cycles within the cave but usually

97 occurring in surface waters, do not invade (Sket, 1999, Graening and Brown, 2003).

98

99 Pollution of groundwater dominated habitats has been implicated as one of the greatest threats

100 to the long term provision of groundwater resources and subterranean biodiversity (e.g.,

101 Boulton, 2005; Danielopol et al., 2003; Hancock et al., 2005) and in particular, cave ecology

102 (e.g., Gunn et al., 2000; Finlay et al., 2006; Panno et al., 2006). However, data clearly

103 demonstrating the ecological impact of pollution within caves are limited due to the

104 difficulties associated with conducting research within subterranean habitats, the absence of

105 pre-disturbance (pollution) data and/or information regarding the source and nature of

106 pollutants (Gunn et al., 2000). Here we examine the response of freshwater cave invertebrates 
to two point-source organic pollution events that occurred during a seven-year study (1997-

108 2003). Our main aims were to gauge the impact of pollution by: (1) quantifying the

109 invertebrate community response to pollution episodes and comparing the impacts of separate

110 events; and (2) investigating changes to the local populations (i.e. extinctions or invasions)

111 resulting from pollution.

113 Methods

114 Study Site

115 The study was undertaken from 1997-2003 within the Peak-Speedwell Cave system,

116 Derbyshire (UK). Peak Cavern and Speedwell Cavern are interconnected and contain more

117 than $16 \mathrm{~km}$ of active (wet) and relict (dry) cave passages that have formed within

118 Carboniferous limestone (karst geology). There is limited hydrological connectivity between

119 the caves, except under high flow (flood) conditions, when water from Speedwell Cavern may

120 rise into the higher passages within Peak Cavern. Water within Peak Cavern is largely derived

121 from autogenic sources (water that has only been in contact with limestone bedrock and

122 overlying soil, and percolates into the cave) which are concentrated into two main

123 subterranean streams that enter the cave from flooded conduits, Ink Sump and Far Sump.

124 These streams flow along the Peak Cavern streamway, enter another flooded conduit and 125 emerge as Peak Cavern Rising, a large spring at the head of Peakshole Water (Figure 1).

126 Water within Speedwell Cavern is largely derived from allogenic sources - twelve streams

127 that flow on the surface over non-limestone geologies before sinking underground. The

128 streams combine underground, enter Speedwell Cavern via two flooded conduits, Main

129 Rising and Whirlpool Rising, flow through the cave, enter another flooded conduit and 130 finally emerge from two springs, Russet Well and Slop Moll, which both flow into Peakshole

131 Water (Gunn et al., 2000). Landuse in both catchments is dominated by livestock grazing, 
132 which has historically resulted in inputs of faecal bacteria to the subterranean ecosystem

133 (Gunn et al., 1998, Hunter et al., 1999).

Detection of pollution and tracing the source

Two major point source pollution episodes were experienced during the study period: (1)

137 during early 1999; and (2) between December 2001-January 2002. Both events occurred

138 when parts of the cave were inaccessible due to flooding and as a result the passage of the

139 pollutant could not be directly monitored in situ. Following the detection of pollution within

140 Peak Cavern due to the first event a survey of the surface catchment identified an orange

141 liquor draining from a large mound into a small stream-sink. The pollutant was organic rich

142 material which was being stock-piled prior to spreading on land as an ameliorant and was

143 principally composed of paper pulp and organic rich peat from a water treatment works. This

144 material formed a mound that covered $>500 \mathrm{~m}^{2}$ to a depth of at least $1 \mathrm{~m}$. When the pollution

145 became evident within Peak Cavern the landowner was asked to take action to prevent

146 runoff/pollution entering the cave. However, the second pollution event occurred after this

147 same material had been partially dispersed on the surface catchment. Once the soils were in a

148 saturated state, following heavy rain in late 2001, water re-entered the same sink holes leading

149 to further degradation.

151 The cave passage downstream of Ink Sump (Figure 1) was heavily stained following both 152 events and the substratum was covered by an orange residue. The staining was observed and 153 reported by recreational cavers and divers but no visible evidence of pollution was detected 154 outside the cave within the springs or river draining the caves (Peakshole Water) during the 155 first event. The second pollution event occurred over a longer period but discolouration of the 156 water was only observed for 24 hours. Hydrological connectivity between the pollutant and 157 the cave was demonstrated by a tracing experiment using two fluorescent dyes, sodium 

were detected at the head of Ink Sump, the most upstream visible point where pollution was

160 recorded within Peak Cavern and also entered Far Sump (the second major percolation input

161 to Peak Cavern - Figure 1). The experiment also indicated that a large proportion of the tracer

162 (and therefore the pollutant) travelled $\sim 4 \mathrm{~km}$ in an easterly direction and was discharged by a

163 natural spring and two anthropogenic sources (soughs) draining water from disused lead

164 mines, and that a small volume of tracer also entered Speedwell Cavern (Wood et al., 2002).

165 Microfloral analysis of water samples from Peak Cavern indicated the presence of a number

166 of cellulose degrading bacteria associated with the biodegradation of the paper pulp following

167 the second event (Hibberd, 2003).

Monitoring and laboratory processing

170 The invertebrate community was routinely sampled monthly over the 7-year period (84

171 months; January 1997- December 2003) from 5 sites within Peak Cavern and from the Peak

172 Cavern Rising $(n=480)$ and from 6 sites $(n=472)$ within Speedwell Cavern (Figure 1).

173 Benthic invertebrates were sampled using a $0.05 \mathrm{~m}^{2}$ cylinder sampler (fitted with a $90 \mu \mathrm{m}$

174 mesh net) over a 30-second period. Additional examination of larger clasts within the cylinder

175 was also undertaken, where they occurred. Due to the potential disturbance and degradation

176 associated with extensive sampling of subterranean habitats single cylinder samples were

177 collected and sampling occasions were used as replicates (Gunn et al., 2000). Sampling could

178 not be undertaken at all sites each month due to flooding of some subterranean passages

179 during the winter and early spring months (5 months within the 84-month study period). At

180 Peak Cavern, three sites were all downstream of the pollution source (Figure 1 - Peak

181 Polluted: PP1, PP2 and PP3) and three sites (control sites) were located on unaffected

182 tributaries (Peak Control: PC1, PC2 and PC3). 
184 All specimens were preserved in the field with 70\% industrial methylated spirits (IMS) and

185 returned to the laboratory for processing and identification. Samples were washed and

186 screened on $250 \mu \mathrm{m}$ and $90 \mu \mathrm{m}$ mesh sieves. Material $>250 \mu \mathrm{m}$ was manually inspected by

187 removing all invertebrates from an illuminated sorting tray. All sediment retained on the

$18890 \mu \mathrm{m}$ mesh sieve was examined in a grooved $(5 \mathrm{~mm})$ Bogorov sorting tray at 10-50

189 magnifications to ensure all material from the samples was examined. All macroinvertebrate

190 taxa were identified to species level where possible. Chironomidae, Oligochaeta and

191 Copepoda specimens were examined individually and mounted on microscope slides for

192 examination (up to 400 magnifications) as required for species level identification.

194 Water temperature $\left({ }^{\circ} \mathrm{C}\right)$, conductivity $\left(\mu \mathrm{S} \mathrm{cm}{ }^{-1}\right)$, $\mathrm{pH}$ and dissolved oxygen $\left(\mathrm{mg} \mathrm{l}^{-1}\right)$ were 195 measured in the field using a portable YSI 600R water quality probe. Replicate water samples 196 were collected from the caves and associated springs and analysed for nitrate $\left(\mathrm{mg} \mathrm{l}^{-1}\right)$ and 197 phosphate $\left(\mathrm{mg} \mathrm{l}^{-1}\right)$ concentrations. Preliminary analysis indicated that there were no 198 significant differences between samples pre- and post-pollution, or between those sites 199 affected by the pollution and those on unaffected tributaries. This reflects the fact that the 200 pollution entered the cave on the flood hydrograph when most of the cave was inaccessible.

202 Data analysis

203 Differences in the invertebrate community between the two caves, and sites affected and 204 unaffected by pollution were examined on an annual basis (calendar year January-December). 205 This corresponded to the timing of flood events and the detection of pollution (disturbance 206 events) within Peak Cavern, and provided 2-years of pre-disturbance data (1997 and 1998), 2207 years when pollution events occurred (1999 and 2002), and 3 other years (2000, 2001 and 208 2003). The invertebrate community was characterised by the following metrics: total 209 abundance (individuals $\mathrm{m}^{-2}$ ), number of taxa, Shannon-Wiener diversity index and the Berger 
210 Parker dominance index. The latter two indices were calculated using the $\alpha$ Species Diversity

211 and Richness software (Pisces Conservation, 1998). Preliminary examination of the data for

212 the different sites and years using Levene's test for homogeneity of variances were significant

213 for some groups $(\mathrm{P}<0.05)$. Hence, the non-parametric Kruskal-Wallis test was applied to

214 examine differences between the caves, polluted and control sites, and for the different time

215 periods.

217 Results

\section{Invertebrate community}

219 A total of 34 aquatic invertebrate taxa were recorded during the study period (Table 2). The

220 pre-disturbance Peak Cavern invertebrate community was dominated by Oligochaeta (5 taxa:

221 Limnodrilus hoffmeisteri, Lumbriculus variegatus, Spirosperma ferox, Stylodrilus sp. and

222 Tubifex tubifex) and Copepoda (4 taxa: Acanthocyclops venustus, A. vernalis, Diacyclops

223 bicuspidatus and Megacyclops viridis) in terms of abundance. Other invertebrate taxa

224 typically comprised less than $15 \%$ of the total abundance for individual sampling occasions.

225 The community within Speedwell Cavern was more variable and was dominated by

226 Oligochaeta (Limnodrilus hoffmeisteri and Tubifex tubifex), Chironomidae (particularly two

227 Orthocladiinae: Rheocricotopus fuscipes and Brillia modesta), Copepoda (Acanthocyclops

228 venustus, A. vernalis, Diacyclops bicuspidatus ) and the amphipod Gammarus pulex. Faunal

229 abundance displayed seasonal variability, demonstrating the influence of epigean inputs of

230 water and organic matter. Examination of the invertebrate communities for the pre-

231 disturbance period (1997 and 1998) indicated that samples from Speedwell Cavern supported

232 a greater abundance of invertebrates, although the community was dominated by a smaller

233 number of taxa compared to Peak Cavern (Kruskal-Wallis test : abundance - $\mathrm{P}<0.001$, Berger

234 Parker dominance $-\mathrm{P}<0.005)$. Samples from Peak Cavern supported a greater number of taxa

235 and had a higher Shannon-Wiener diversity than Speedwell Cavern (Kruskal-Wallis test: 
number of taxa $-\mathrm{P}<0.001$; Shannon-Wiener $-\mathrm{P}<0.001$ - see Wood et al., 2002 for further

237 details).

Pollution episode 1

At sites affected by pollution in Peak Cavern no benthic invertebrates were recorded in the

241 month after the pollution event, although a large number of dead and decaying earthworms

242 (Lumbricus terrestris) were recorded at the channel margins. The abundance of freshwater

243 taxa remained low at polluted sites for the rest of the year compared with control sites (Figure

244 2), with the invertebrate community being almost exclusively composed of two oligochaetes

245 (Limnodrilus hoffmeisteri and Tubifex tubifex). The first pollution episode resulted in a

246 significant reduction in the abundance at affected sites (1999 in Figure 3a) compared to pre-

247 disturbance data (1997 and 1998 in Figure 3a) and control sites (Figure 3b). A similar pattern

248 was observed for the number of taxa and the Shannon-Wiener diversity index, and an inverse 249 pattern for the Berger-Parker dominance index (see Table 3 for pair-wise comparisons). No

250 significant differences in benthic abundance, number of taxa, Shannon-Wiener diversity or

251 Berger Parker dominance were recorded between the polluted and control sites within Peak

252 Cavern in the following 2 years (2000 and 2001) (Table 3), and there were no differences in

253 any invertebrate community parameters for Speedwell Cavern between the pre-disturbance

254 (1997 and 1998), disturbance (1999) or post-disturbance periods (2000 and 2001).

Pollution episode 2

257 As a result of the second input of pollutant in 2002, a significant increase in benthic

258 abundance occurred at the affected sites within Peak Cavern (Figure 3a) compared with two

259 of the control sites (Figure 3b). A similar pattern was observed for the Berger-Parker

260 dominance index and an inverse pattern for the number of taxa and the Shannon-Wiener

261 diversity index (see Table 3 for pair-wise comparisons). The abundances of two oligochaetes 
262 (Limnodrilus hoffmeisteri and Tubifex tubifex) increased significantly (to $>500 \mathrm{~m}^{-2}$ ) within

263 one month of the input of the pollutant (Kruskal-Wallis test $-\mathrm{P}<0.001$ ). In the following

264 months, numbers of the epigean amphipod, Gammarus pulex, also increased significantly at 265 polluted sites compared with two control sites (Kruskal-Wallis test $-\mathrm{P}<0.001$ ). In February

266 2002, G. pulex was recorded for the first time during the study period at one control site (PC1

267 in Figure 1). Following the discovery of G. pulex at the site the total abundance of

268 invertebrates, particularly Oligochaeta and Copepda, was reduced compared to the other 269 control sites (Figure 4a-e). No significant differences between any invertebrate community 270 parameters were recorded for Speedwell Cavern following the second pollution episode.

272 Discussion

273 The nature of cave pollution and disturbance

274 Differences in the physical nature of perturbations, in the form of pulse, press and ramp 275 disturbances can result in multiple and markedly different biotic responses within aquatic 276 ecosystems (sensu Lake, 2000). Pollution disturbances of groundwater dominated ecosystems 277 can be associated with both press and pulse disturbances. Press disturbances are typically 278 associated with the diffuse entry of material from a relatively large geographical area which 279 percolates into the subterranean groundwater environment (Hancock et al., 2005; Rinaudo et 280 al., 2005). Pulse events are usually associated with the rapid transfer of material into the 281 subterranean environment from a specific location within the surface catchment and may be 282 associated with high water input (Culver et al., 1992; Graening and Brown, 2003). Both of the 283 events recorded in this investigation were clearly point-source disturbances associated with

284 flood events. However, flood events occurring between the two pollution events, during 2000 285 and 2001, did not appear to result in any significant input of pollutant and acted as 'flushing 286 flows' which facilitated the recovery of the benthic invertebrate community (abundance, 287 number of taxa, diversity and dominance) to pre-disturbance levels (Figure 3). 
289 Both pollution events resulted in significant changes to the benthic invertebrate community of

290 affected sites within Peak Cavern. However, no impact was recorded within the adjacent

291 system (Speedwell Cavern) despite water tracing experiments indicating limited hydrological

292 connectivity with the stream-sink through which the pollutant entered the groundwater system

293 (Wood et al., 2002). This reflects the different hydrological characteristics of the two caves.

294 Water in Speedwell Cavern is primarily derived from sinking streams and as a result the

295 residence time of water within the cave is short, dissolved and particulate organic matter input

296 is relatively high, and pollutants are likely to be diluted and transported through the system

297 relatively quickly (Gunn et al., 2000; Simon et al., 2003). In contrast, water within Peak

298 Cavern is principally derived from percolation water that has passed through the overlying

299 soil and rock and, as a result, the residence time of water is longer. In addition, the volume

300 and delivery of dissolved and particulate organic matter and abundance of invertebrates is

301 usually lower within percolation water dominated systems such as Peak Cavern (Poulson and

302 Lavoie, 2000; Simon et al., 2003). These natural hydrological characteristics reflect a well

303 know gradient of differences that strongly influences the volume, timing and processing rate

304 of trophic resources within subterranean ecosystems (e.g., Poulson and Lavoie, 2000; Simon

305 and Benfield, 2001, Simon et al., 2003).

306

307 Faunal response to pollution

308 Faunal response to the pollution events was marked and indicative of significant disturbance

309 events. Direct faunal community response to the pollution of caves has only been recorded in

310 a limited number of previous studies (e.g. Culver at al., 1992), with several studies comparing

311 degraded systems with reference sites in the absence of non-affected control sites (e.g.

312 Holsinger, 1966, Simon and Buikema, 1997). Few studies have included detailed pre- and

313 post-disturbance data or have been undertaken over a comparable length of time. The greatest 
314 changes to the invertebrate community of Peak Cavern were associated with a limited number

315 of taxa (2 oligochaetes: Limnodrilus hoffmeisteri and Tubifex tubifex, the amphipod

316 Gammarus pulex and 4 Copepoda - Acanthocyclops venustus, A. vernalis, Diacyclops

317 bicuspidatus and Megacyclops viridis).

319 During the period immediately following both pollution episodes the invertebrate community 320 at affected sites was dominated by the oligochaetes Limnodrilus hoffmeisteri and Tubifex

321 tubifex. Both of these taxa are widespread, occur in most surface waters and have been

322 recorded from caves across the globe where they have been associated with organic

323 enrichment (Swayne et al., 2004; Wetzel and Taylor, 2001). During the first pollution event

324 densities were lower than baseline conditions $\left(<50 \mathrm{~m}^{-2}\right)$ and during the second event they

325 were significantly higher $\left(>200 \mathrm{~m}^{2}\right)$ at degraded sites (Figure 3). Their dominance of the

326 invertebrate community within Peak Cavern during these events suggests they are relatively

327 resilient and good indicators of organic pollution within caves and other groundwater

328 dominated ecosystems (Lafont et al., 1996; Lafont and Vivier, 2006).

330 The increased abundance of cyclopoid copepods following the input of organic material

331 during the second event probably reflects an increased food supply for these taxa. Several 332 cyclopoid copepods (including those in the genus Acanthocyclops ) are known to be predatory 333 (Fryer, 1957; Galassi et al., 2002), feeding on taxa such as ciliates, rotifers, small oligochaetes 334 and other small crustaceans, all of which may have increased abundances in conditions of 335 high organic matter. At the same time, other cyclopoid taxa are more reliant on fine detrital 336 material (Galassi et al., 2002) that, again, is likely to be more plentiful during an organic 337 pollution event. The abundance of Gammarus pulex also increased ( $>20$ individuals $\mathrm{m}^{-2}$ ) at 338 affected sites as a result of the second pollution episode, as well as invading one of the 339 adjacent control sites. G. pulex have been recorded in many cave systems in the UK, where 
340 they frequently occur in relatively high abundances (Proudlove et al., 2003). Stygophilic

341 gammarids have been recorded within a number of caves around the world where some

342 populations display adaptations to the subterranean environment (e.g. Culver et al., 1995).

343 Epigean Gammarus species have been widely reported to be highly competitive and invasive

344 in some instances (MacNeil et al., 2003). It is now widely acknowledged that some

345 gammarids are omnivorous and may be active and effective predators (Kelly et al., 2002) and

346 the invasion of epigean (stygophilic) taxa into subterranean habitats may result in the

347 displacement and/or elimination of hypogean (stygobitic) taxa (Sket, 1977).

349 The aquatic invertebrate communities of both caves were almost exclusively composed of 350 stygophiles, and none can be regarded as obligate subterranean taxa (stygobites); although the 351 larvae of the dytiscid beetle Hydroporus ferrugineus has only been recorded from the Peak352 Speedwell system and may be an obligatory subterranean life stage (Alarie et al., 2001). No 353 stygobitic taxa have been recorded from 48 karstic springs within the wider limestone region 354 of the English Peak District (Wood et al., 2005), suggesting that the absence of stygobitic 355 fauna from the Peak-Speedwell Cavern system is not due to pollution alone. Absence of 356 hypogean taxa may reflect glacial activity during the Pleistocene, the maximum extent of 357 which was thought to mark the limits of subterranean faunal distributions. However, there is 358 increasing evidence that stygobitic fauna persisted in sub-glacial refugia beneath the ice in 359 many areas (e.g. Holsinger et al., 1997) including the UK where stygobitic taxa have been 360 recorded some distance north of the maximum extent of glaciation (Proudlove et al., 2003;

361 Bratton, 2006).

Parallels and contrasts between pollution events

364 A number of parallels and contrasts between the events and their impact on the cave 365 ecosystem can be identified. Both of the pollution events recorded during the study period 
coincided with floods and originated from the same location within the surface catchment.

367 The impact on the benthic community at polluted sites was rapid (one month following their

368 detection) and persisted until the next major flood event. However, the response of the 369 community and individual taxa to the two events was markedly different. The first pollution 370 episode resulted in a significant reduction in community abundance, number of taxa and

371 Shannon- diversity index but an increase in the Berger-Parker dominance index at affected 372 sites. The second episodes led to a marked increase in the community abundance and Berger-

373 Parker dominance index, and a reduction in the number of taxa, and Shannon- diversity index.

374 The differences in the community response to the events probably reflects differences in the 375 magnitude of the flood events and associated pollutant loading. The first event resulted in the 376 input of pollutants which were largely contained within the cave and led to the exclusion of 377 almost all fauna from affected sites. The second event was associated with a period of 378 sustained high flow and it is likely that a large proportion of the pollutant was transported 379 through the cave, and was observed as discolouration of the water emerging from Peak 380 Cavern Rising. The pollution load retained within the cave associated with the second event 381 was probably lower, did not lead to sub-lethal concentrations and may have actually enhanced 382 the trophic resources available within the cave leading to the marked increase in the 383 abundance of some members of the invertebrate community (Graening and Brown, 2003; 384 Simon and Buikema, 1997; Sket, 1999).

386 Recovery of the benthic community was relatively rapid following both pollution events, 387 possibly due to the presence of a large number of refugia within non-polluted sites.

388 Subsequent flooding of the cave in the proceeding years (2000 and 2003 respectively) 389 appeared to "cleanse" the system of the pollutant and facilitated the recovery of fauna at all 390 sites following the first event and all but one site (which was invaded by Gammarus pulex) 391 following the second (Figure 3 and Figure 4). In other studies, recovery of aquatic cave 
invertebrate communities following pollution disturbances has not been as rapid as reported in

393 the current investigation and the impacts have persisted for some time (in excess of 3-years -

394 see Culver et al., 1992). However, data on recovery times for cave communities are usually

395 absent (Graening and Brown, 2003, Simon and Buikema, 1997), reflecting the long-term and

396 diffuse nature of the impact of pollution on some systems but also the fragility of cave

397 ecosystems, the difficulty of undertaking research in subterranean environments and the

398 paucity of pre-disturbance baseline data available for most systems. In the case of the Peak-

399 Speedwell Cavern system, the relatively rapid recovery may have reflected the legacy of

400 impacts upon the subterranean ecosystem (Gunn et al., 2000). This may also explain the

401 absence of stygobitic taxa which are less competitive and more vulnerable to pollution

402 disturbances than most stygophilic taxa (Graening and Brown, 2003; Panno et al., 2006; Sket, 403 1999).

404

405

Implications for conservation and management

406 Managing groundwater/subterranean ecosystems is particularly difficult since the most

407 damaging activities usually occur in the surface catchment (van Beynen and Townsend, 2005;

408 Danielopol et al., 2003; Gunn et al., 2000). There may be an extended time-period between a

409 disturbance event occurring in the surface catchment and its detection within the subterranean

410 system, by which time irreversible damage may have already occurred (Hancock et al., 2005).

411 Even after the detection of any pollutant, tracing the source may be problematic because the

412 pollution may have ceased and/or the input may be episodic, as recorded in the current

413 investigation.

415 In Great Britain (England, Wales, Scotland), the major mechanism for legally protecting, and 416 thereby conserving wildlife and earth science features is through notification as a 'Site of

417 Special Scientific Interest’ (SSSI). A list of “operations likely to damage the special interest” 
418 is issued to each owner of land in the boundaries of a SSSI at the time the site is designated

419 and the relevant country authority (Natural England, Countryside Council for Wales, Scottish

420 Natural Heritage) must be consulted before any of the listed operations are undertaken. If it is

421 considered that the proposed action will damage the scientific interest of the site then

422 permission may be denied and the authority may enter into a management agreement with the

423 land owner. Following a Geological Conservation Review (GCR) which began in 1977 (Ellis

424 et al., 1996) 48 'cave’ sites were identified and subsequently have been designated as SSSI.

425 Descriptions and evaluations of the geomorphological evolution of each Cave and Karst GCR 426 site have been published (Waltham et al., 1997). At the time of the GCR the boundaries of the 42748 sites encompassed 879 named caves, 30\% of the total caves in Britain (Hardwick and Gunn, 428 1996). These 879 caves included all of the longer cave systems so that $\sim 75 \%$ of known cave 429 passage (and hence of the total cave resource) was within areas proposed for conservation.

431 Some of the caves designated as SSSIs in Great Britain were base on their biological interest, 432 although almost exclusively on the basis of bats (Chiroptera) and/or bat roosts. Aquatic 433 invertebrates are only listed as an additional reason for notification at one site (Pridhamsleigh 434 Cave SSSI, Devon) where Niphargus glenniei (Crustacea: Amphipoda), an endemic amphipod 435 which is abundant within the cave, occurs. The Peak-Speedwell Cavern system forms part of a 436 Site of Special Scientific Interest (SSSI) but its designation only covers the earth science 437 interests and does not include any subterranean ecological/biological interests (Gunn et al., 438 2000). However, designation of a cave SSSI does provide limited, even if unintentional, 439 protection for aquatic cave ecosystems and the communities they support because each SSSI has 440 a list of 'operations requiring consent'. These have been drawn up to protect the earth science 441 features of interest but by providing controls on water quality and water quantity they may also 442 benefit the whole subterranean ecosystem. Initially the protection of sites was confined to 443 operations on the overlying land surface and the land owner was held responsible for any 
444 infringement. However, in England and Wales, part of the Countryside and Rights of Way Act 4452000 (CROW) makes it possible for action to be taken against any person damaging the 446 scientific interest of a SSSI even if the action took place outside the SSSI boundaries. As the 447 current research demonstrates, this is particularly important in the case of active cave systems 448 that often receive inputs of water from surface streams whose catchment is outside of the 449 SSSI. All notified water pollution incidents, whether outside or inside of a SSSI, are subject to 450 investigation by the Environment Agency (England and Wales) or the Scottish Environment 451 Protection Agency. However, if the investigating agency is unaware of the composition, sensitivity or even existence of potentially vulnerable aquatic communities in caves then their conservation is not likely to be considered. Knowledge regarding subterranean biodiversity 454 and its conservation value in the UK is severely limited due to an absence of historic and 455 contemporary scientific research compared to other geographical localities (e.g., Ferreira et al., 456 2007; Culver et al., 2000) and therefore requires an urgent reassessment.

Many obligate aquatic subterranean organisms (stygobites) are confined to relatively small geographical locations (Christman et al., 2005; Ferreira et al., 2007), and display 460 morphological and physiological adaptations to their environment (Coineau, 2000, Culver et 461 al., 1995). As a result, many aquatic cave communities are scientifically important and of high conservation value (Sket, 1999). Managing and mitigating the effects of organic pollution

463 within groundwater dominated habitats may be particularly difficult due to the highly diffuse 464 nature in which many pollutants enter aquifers and cave ecosystems (Boulton, 2005; Sket, 465 1999) and the long residence time of water compared to epigean riverine systems. Across 466 North America and in some Europe countries, a greater awareness of subterranean 467 biodiversity exists (Culver et al., 2000; Ferreira et al., 2007; Sket, 1999), and some faunal 468 species have been recognised as threatened by the International Union for Conservation of 469 Nature and Natural Resources (IUCN 2006). However, conservation of subterranean fauna is 
470 problematic since while individual species and caves may be protected, the wider community

471 and the surface catchment usually have limited or no protection.

472

473 There is a growing need to consider the importance of groundwater quality within

474 subterranean systems since it has major implications for obligate subterranean taxa, and may

475 ultimately have a significant impact on surface waters and their ecology (Boulton, 2005,

476 Hancock, 2002). However, the identification of indicator organisms and the development of

477 biotic indices for groundwater dominated ecosystems, including caves, are currently limited

478 (e.g. Lafont et al., 1996; van Beynen and Townsend, 2005; Hahn, 2006). Greater awareness

479 regarding the impact and implication of disturbances, particularly pollution, upon

480 groundwater dominated ecosystems is required. Given the limited biological monitoring of

481 subterranean groundwater dependant ecosystems, and the largely unseen consequences of

482 pollution within them, a significant knowledge gap exists regarding their impacts. Future

483 research should address these issues to ensure the continued conservation and protection of

484 subterranean faunal communities and the subterranean and surface water ecosystems within

485 the wider drainage basin.

486

487 Acknowledgements

488 PJW acknowledges the support of the British Ecological Society (Small Ecological Project

489 Grant - 1371) and the Natural Environment Research Council (NER/M/S/1999/00152 and

490 GR8/04287) for funding parts of this research. Thanks to Dr Paul Hardwick, Laura Chapman,

491 Garry Rushworth, Robin Kenyon and Richard Battye for field and laboratory assistance and

492 to John Harrison and Tony Marsden for providing access to the caves. Thanks to Prof. P.

493 Armitage, J. Blackburn, G. Fryer, M. Greenwood and Dr D. Horne for confirmation of faunal

494 identifications. Thanks to Ben Le Bas (Natural England) and David Ottewell (Environment 
Agency for comments on cave conservation and management; and to Phil Boon and an

anonymous reviewer for comments on a draft of this manuscript.

497

498

References

499

Alarie Y, Wood PJ, DeBruyn AMH, Cuppen JGM. 2001. Description of the larvae of

500 Hydroporus ferrugineus Stephens and H. polaris Fall (Coleoptera: Adephaga: Dytiscidae).

$501 \quad$ Aquatic Insects 23: 123-133.

502

van Beynen PV, Townsend K. 2005. A disturbance index for karst environments.

503 Environmental Management 36: 101-116.

504 Boulton AJ. 2005. Chances and challenges in the conservation of groundwaters and their 505 dependent ecosystems. Aquatic Conservation: Marine and Freshwater Ecosystems 15:

507 Bratton JH. 2006. Occurrence of the well shrimp Niphargus aquilex (Crustacea: Niphargidae) 508 in Anglesey, North Wales, UK. Cave and Karst Science 33: 29-30.

Christman MC, Culver DC, Madden MK, White D. 2005. Patterns of endemism of the eastern North American cave fauna. Journal of Biogeography 32: 1441-1452.

511 Coineau N. 2000. Adaptations to interstitial groundwater life. In Subterranean Ecosystem: 512 Ecosystems of the World. 30, Wilkins H, Culver DC, Humphries WF (eds). Elsevier 513 Science: Amsterdam, The Netherlands; 189-210.

514 Culver DC. 1985. Trophic relationships in aquatic cave environments. Stygologia 1: 43-53. 515 Culver DC, Jones WK, Holsinger JR. 1992. Biological and hydrological investigation of the 516 Cedars, Lee County, Virginia, an ecologically significant and threatened karst area. In 517 Proceedings of the $1^{\text {st }}$ International Conference on Ground Water Ecology, Stanford JA, 518 Simons JJ (eds). American Water Resources Association: Bethesda, MD: 281-290. 519 Culver DC, Kane TC, Fong DW. 1995. Adaptation and Natural Selection in Caves: The 520 Evolution of Gammarus minus. Harvard University Press: Cambridge, Massachusetts. 
521 Culver DC, Master LL, Christman, MC and Hobbs HH III 2000. Obligate cave fauna of the 52248 contiguous United States. Conservation Biology 14: 386-401.

523 Culver DC, Sket B. 2000. Hotspots of subterranean biodiversity in caves and wells. Journal of $524 \quad$ Cave and Karst Studies 62: 11-17.

525 Danielopol DL, Griebler C, Gunatilaka A, Notenboom J. 2003. Present state and future 526 prospects for groundwater ecosystems. Environmental Conservation 30: 104-130.

527 Elliott WR. 2000. Conservation of the North American cave and karst biota. In Subterranean 528 Ecosystem: Ecosystems of the World. 30, Wilkins H, Culver DC, Humphries WF (ed). 529 Elsevier Science: Amsterdam, The Netherlands; 665-689.

530 Ellis NV, Bowen, DQ, Campbell S, Knill JL, McKirdy AP, Prosser CD, Vincent MA, Wilson 531 RCL. 1996. An introduction to the Geological Conservation Review. London, Chapman $532 \quad$ Hall.

533 Ferreira D, Malard F, Dole-Olivier MJ, Gibert J. 2007. Obligate groundwater fauna of France: 534 diversity patterns and conservation implications. Biodiversity and Conservation 16: 567$535 \quad 597$.

536 Finlay JB, Buhay, JE Crandall KA. 2006. Surface to subsurface freshwater connections :

537 phylogeographic and habitat analyses of Cambarus tenebrosus, a facultative cave$538 \quad$ dwelling crayfish. Animal Conservation 9: 375-387.

539 Fryer G. 1957. The food of some freshwater cyclopoid copepods and its ecological $540 \quad$ significance. Journal of Animal Biology 26: 263-286.

541 Galassi D, Marmonier P, Dole-Olivier M-J, Rundle SD. 2002. Microcrustacea. In Freshwater 542 Meiofauna: Biology and Ecology, Rundle SD, Robertson AL, Schmid-Araya JM (eds). 543 Backhuys Publishers: Leiden, The Netherlands; 135-175.

544 Graening GO, Brown AV. 2003. Ecosystem dynamics and pollution effects in an Ozark cave 545 stream. Journal of the American Water Resources Association 36:1497-1507. 
546 Green WD,Elliott LP, Crawford NC. 1990. Investigation on nonpoint source pollution

547 associated with karst aquifer systems. Transactions of the Kentucky Academy of Science

$548 \quad 51: 177-181$

549 Gunn J, Tranter J, Perkins J, Hunter C. 1998. Sanitary Bacterial Dynamics in a Mixed Karst 550 Aquifer. In Karst Hydrology, Leibungut, C, Gunn, J. Dassargues A. (eds.). Publication $551 \quad$ 247, IAHS; 61-70.

552 Gunn J, Hardwick P, Wood PJ. 2000. The invertebrate community of the Peak-Speedwell 553 cave system, Derbyshire, England - pressures and considerations for conservation 554 management. Aquatic Conservation: Marine and Freshwater Ecosystems 10: 353-369.

Hahn HJ. 2006. The GW-Faunal-Index: A first approach to a quantitative ecological assessment of groundwater habitats. Limnologica 36: 119-137.

557 Halliday WR. 2003. Raw sewage and solid waste dumps in lava tube caves of Hawaii Island. $558 \quad$ Journal of Cave and Karst Studies 65:68-75.

559 Hancock PJ. 2002. Human impacts on the stream-groundwater exchange zone. Environmental Management 29: 763-781.

561 Hancock PJ, Boulton AJ, Humphreys WF. 2005. Aquifers and hyporheic zones: Towards an 562 ecological understanding of groundwater. Hydrogeology Journal 13: 98-111.

563 Hardwick P, Gunn J. 1996. The conservation of Britain’s limestone cave resource. $564 \quad$ Environmental Geology 28: 121-127.

565 Hibberd L. 2003. The impact of agricultural paper pulp on the microflora of a Derbyshire $566 \quad$ Karst. Unpublished Thesis, University of Huddersfield, UK.

567 Holsinger JR. 1966. A preliminary study of the effects of organic pollution of Banners Corner 568 Cave, Virginia. International Journal of Speleology 2: 75-89.

569 Holsinger JR. 1988. Troglobites - The evolution of cave dwelling organisms. American $570 \quad$ Scientist 76: 146-153. 
571 Holsinger JR, Carlson KR, Shaw DP. 1997. Biogeographic significance of recently

572 discovered amphipod crustaceans (Stygobromus) in caves of southeastern Alaska and

573 Vancouver Island. In Proceedings of the $12^{\text {th }}$ International Congress of Speleology, 10-

$574 \quad 17^{\text {th }}$ August 1999, La Chaux-de-Fonds: Switzerland; 347-349.

575 Hunter C, Perkins J, Tranter J, Gunn J. 1999. Agricultural land-use effects on the indicator 576 bacterial quality of an upland stream in the Derbyshire Peak District in the UK. Water $577 \quad$ Research 33: 3577-3586.

578 IUCN 2006. 2006 IUCN Red List of Threatened Species. <www.iucnredlist.org>.

$579 \quad$ Downloaded on 21 August 2007.

580 Jasinska EJ, Knott B, McComb AJ. 1996. Root mats in ground water: a fauna-rich cave

581 habitat. Journal of the North American Benthological Society 15: 508-519.

582 Kelly DW, Dick JTA, Montgomery WI. 2002. The functional role of Gammarus (Crustacea, 583 Amphipoda): shredders, predators or both. Hydrobiologia 485: 199-203.

584 Lafont M, Camus JC, Rosso A. 1996. Superficial and hypoheic oligochaeta communities as 585 indicators of pollution and water exchange in the River Moselle, France. Hydrobiologia $586 \quad 334: 147-155$.

587 Lafont M, Vivier A. 2006. Oligochaete assemblages in the hypoheic zone and coarse surface 588 sediments: Their importance for understanding of ecological functioning of watercourses. $589 \quad$ Hydrobiologia 546: 171-181.

590 Lake PS. 2000. Disturbance, patchiness, and diversity in streams. Journal of the North 591 American Benthological Society 19: 573-592.

592 MacNeil C, Bigsby E, Dick JTA, Hatcher MJ, Dunn AM. 2003. Differential physico-chemical 593 tolerances and intraguild predation among native and invasive amphipods (Crustacea); a 594 field study. Archiv für Hydrobiologie 156: 165-179. 
Panno SV, Hackley KC, Kelly WR, Hwang HH, Wilhelm FM, Taylor SJ, Stiff BJ. 2006. Potential effects of recurrent low oxygen conditions on the Illinois cave amphipod. Journal of Cave and Karst Studies 68: 55-63.

Pisces Conservation. 1998. $\alpha$ Species Diversity and Richness, Pisces Conservation Ltd. Lymington, Hampshire, UK.

600 Poulson TL, Lavoie KH. 2000. The trophic basis of subsurface ecosystems. Subterranean 601 Ecosystem: Ecosystems of the World, 30,. In Wilkins H, Culver DC, Humphries WF (eds). 602 Elsevier Science: Amsterdam, The Netherlands; 231-249.

603 Proudlove GS, Wood PJ, Harding PT, Horne DJ, Gledhill T, Knight LRFD. 2003. A review 604 of the status and distribution of the subterranean aquatic Crustacea of Britain and Ireland. $605 \quad$ Cave and Karst Science 30: 51-74.

606 Rinaudo JD, Arnal C, Blanchin R, Elsass R, Meilhac A, Loubier S. 2005. Assessing the cost 607 of groundwater pollution: the case of diffuse agricultural pollution in the Upper Rhine 608 valley aquifer. Water Science and Technology 52: 153-162.

609 Simon KS, Benfield EF. 2001. Leaf and wood breakdown in cave streams. Journal of the $610 \quad$ North American Benthological Society 20: 550-563.

611 Simon KS, Buikema AL. 1997. Effects of organic pollution on an Appalachian cave: changes 612 in macroinvertebrate population and food supplies. American Midland Naturalist 138: $613 \quad 387-401$.

614 Simon KS, Benfield EF, Macko SA. 2003. Food wed structure and the role of epilithic 615 biofilms in cave streams. Ecology 84: 2395-2406.

616 Sket B. 1977. Gegenseitige beeinflussung der wasserpollution und des höhlenmilieus. 617 Proceedins of the $6^{\text {th }}$ International Congress of Speleology. 5: 253-262.

618 Sket B. 1999. The nature of biodiversity in hypogean waters and how it is endangered. 619 Biodiversity and Conservation 8: 1319-1338. 
620 Swayne H, Day M, Wetzel MJ. 2004. Limnodrilus hoffmeisteri (Annelida: Oligochaeta:

621 Tubficidae) in Pop's Cave, Wisconsin, USA. Journal of Cave and Karst Studies 66: 28-31.

622 Waltham AC, Simms MJ, Farrant AR, Goldie HS. 1997. Karst and Caves of Great Britain.

623 Chapman and Hall, London 358pp.

624 Wetzel MJ, Taylor SJ. 2001. First records of freshwater oligochaetes (Annelida, Clitellata)

625 from caves in Illinois and Missouri, USA. Journal of Cave and Karst Studies 63: 99-104.

626 Wood PJ, Gunn J, Perkins J. 2002. The impact of pollution on aquatic invertebrates within a

627 subterranean ecosystem - out of sight out of mind. Archiv für Hydrobiologie 155: 223-237.

628 Wood PJ, Gunn J, Smith H, Abas-Kutty A. 2005. Flow permanence and macroinvertebrate

629 community diversity within groundwater dominated headwater streams and springs.

$630 \quad$ Hydrobiologia 545: 55-64.

631

632 
List of Figures

634 Figure 1. The Peak-Speedwell Cavern system indicating the location of invertebrate sampling

635

636

637

638

639

640

641

642

643

644

645

646

647

648

649

650

651

652

653

654

655

656 sites within Speedwell Cavern (1-6), Peak Cavern control sites (PC1-PC3), polluted sites (PP1-PP3) and other specific locations referred to within the text.

Figure 2. Mean invertebrate community abundance (individuals $\mathrm{m}^{-2} \pm 1 \mathrm{SE}$ ) within Peak Cavern (January 1999-December 1999) for: (a) control sites and (b) polluted sites.

Figure 3. Mean invertebrate community abundance (individuals $\mathrm{m}^{-2}$ ) and $95 \%$ confidence intervals for the Peak Cavern benthic invertebrate community (January 1997December 2003) for: (a) polluted sites; and (b) control sites. * Indicates control site (PC1) not included in the series due to invasion of the site by Gammarus pulex.

Figure 4. Invertebrate community abundance for unpolluted control sites within Peak Cavern (January 1999-December 1999): (a) mean abundance of all taxa (individuals $\mathrm{m}^{-2} \pm$ $1 \mathrm{SE}$ ) from control site 2 and 3 (PC2 and PC3); (b) abundance (individuals $\mathrm{m}^{-2}$ ) of all taxa from control site 1 (PC1); (c) mean abundance of dominant Oligochaeta (Limnodrilus hoffmeisteri and Tubifex tubifex individuals $\mathrm{m}^{-2} \pm 1 \mathrm{SE}$ ) from control site 2 and 3 (PC2 and PC3); (d) abundance of dominant Oligochaeta (Limnodrilus hoffmeisteri and Tubifex tubifex individuals $\mathrm{m}^{-2}$ ) from control site 1 (PC1); (e) mean abundance of dominant Copepoda (Acanthocyclops venustus, A. vernalis, Diacyclops bicuspidatus and Megacyclops viridis individuals $m^{-2} \pm 1$ SE) from control site 2 and 3 (PC2 and PC3); and (f) abundance of dominant Copepoda (Acanthocyclops venustus, A. vernalis, Diacyclops bicuspidatus and Megacyclops viridis individuals $\mathrm{m}^{-2}$ ) from control site 1 (PC1). Solid line indicates the timing of pollution input and dashed line indicates the first record of Gammarus pulex at control site 1 (PC1). 





Figure 2
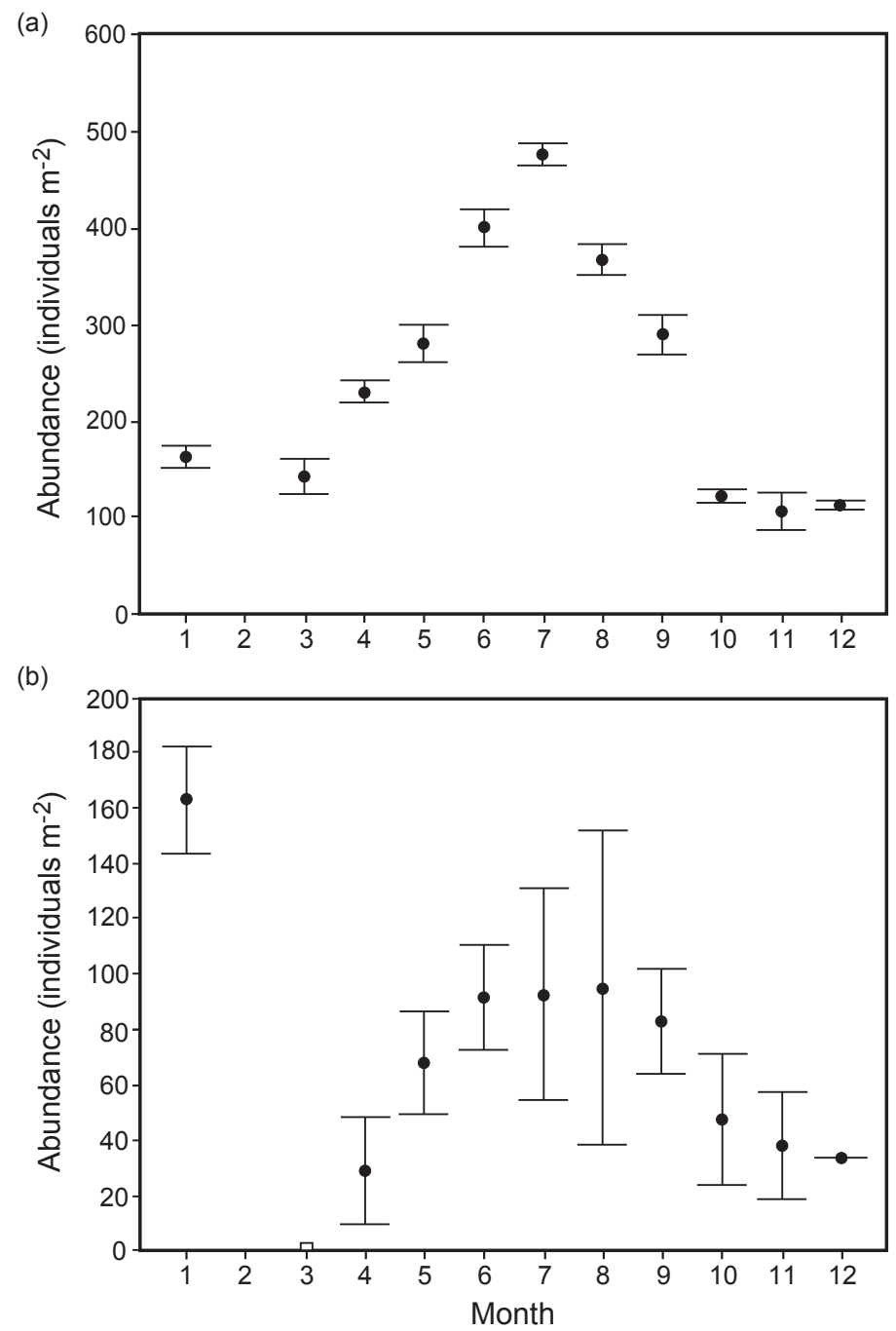
Figure 3

Figure 4

(a)


(d)
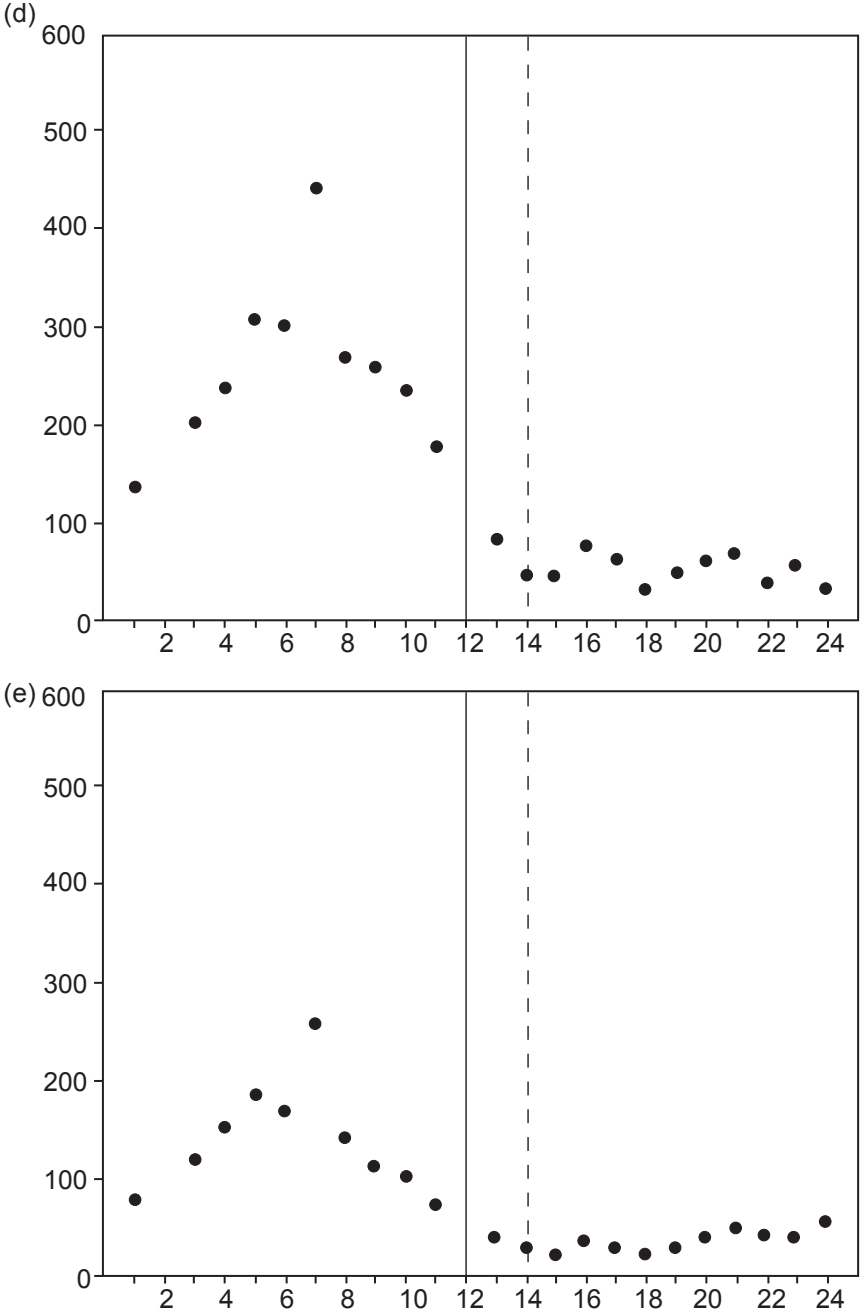

(f) 600

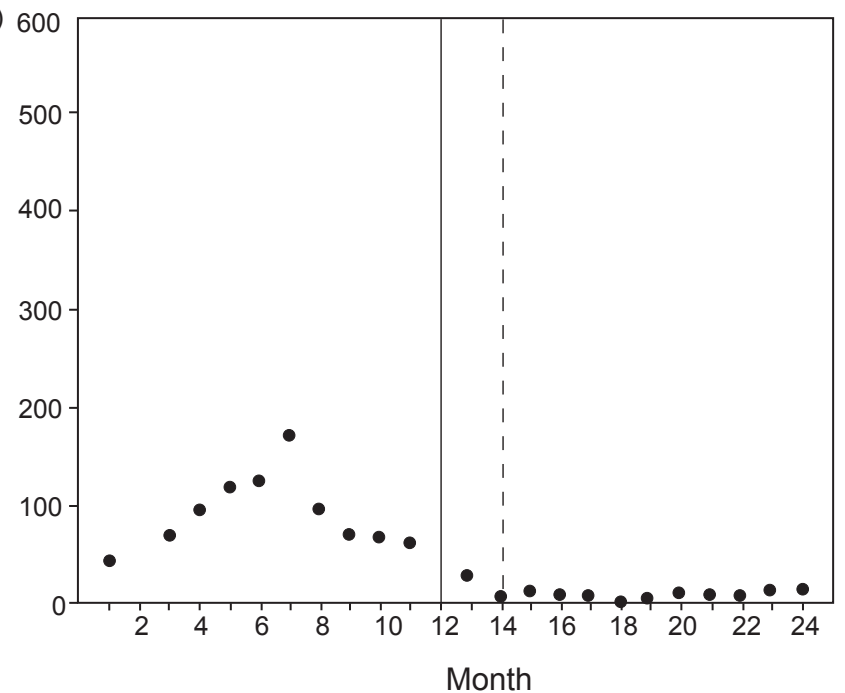


Table 1. Summary of scientific papers documenting the impact of organic pollution on aquatic invertebrate communities and fauna within

\begin{tabular}{|c|c|c|c|}
\hline Author & Location & Pollution & Impact \\
\hline Culver et al. 1992 & $\begin{array}{l}\text { Thompson Cedar } \\
\text { Cave, Virginia, USA }\end{array}$ & $\begin{array}{l}\text { Sawdust and Bark from Sawmill } \\
\text { Operation }\end{array}$ & $\begin{array}{l}\text { Elimination of stygobitic amphipod and isopod populations. } \\
\text { An increase in the abundance of epigean (stygophilic) } \\
\text { Oligochaeta (Tubificidae) and Chironomidae larvae. } \\
\text { Limited recovery three-years after the event. }\end{array}$ \\
\hline $\begin{array}{l}\text { Graening and } \\
\text { Brown } 2003\end{array}$ & $\begin{array}{l}\text { Cave Springs Cave, } \\
\text { Arkansas, USA }\end{array}$ & $\begin{array}{l}\text { Septic leachate, sewage sludge and } \\
\text { cow manure suspected }\end{array}$ & $\begin{array}{l}\text { Elimination of stygobitic amphipods although stygobitic } \\
\text { isopods flourished. }\end{array}$ \\
\hline Holsinger 1966 & $\begin{array}{l}\text { Banners Corner Cave, } \\
\text { Virginia, USA }\end{array}$ & Septic leachate (sewage) & $\begin{array}{l}\text { An increase in the abundance of stygobitic isopod and } \\
\text { Planaridae populations at the same time an increase in } \\
\text { abundance of epigean (stygophilic) fauna occurred. }\end{array}$ \\
\hline Panno et al. 2006 & $\begin{array}{l}\text { Illinois' sinkhole plain, } \\
\text { Illinois, USA }\end{array}$ & Septic leachate (sewage) & $\begin{array}{l}\text { Elimination of a stygobitic amphipod (Gammarus } \\
\text { acherondytes) from one polluted system and recovery in } \\
\text { an adjacent system. }\end{array}$ \\
\hline $\begin{array}{l}\text { Simon and } \\
\text { Buikema } 1997\end{array}$ & $\begin{array}{l}\text { Banners Corner Cave, } \\
\text { Virginia, USA }\end{array}$ & Septic leachate (sewage) & $\begin{array}{l}\text { Absence of stygobitic isopods from highly polluted pools, } \\
\text { but common occurrence in moderately and slightly polluted } \\
\text { waters. Exclusion of stygobitic Amphipods from any } \\
\text { polluted waters. }\end{array}$ \\
\hline Sket 1977 & $\begin{array}{l}\text { Various cave systems, } \\
\text { Dinaric Karst, } \\
\text { Slovenia }\end{array}$ & $\begin{array}{l}\text { Organic enrichment } \\
\text { Organic enrichment } \\
\text { Organic enrichment }\end{array}$ & $\begin{array}{l}\text { Podpeška jama - Increase in abundance of stygobitic } \\
\text { fauna in the absence of epigean (stygophilic) competitors - } \\
\text { which had no access to the site. } \\
\text { Jama v Šahnu - elimination of all stygobitic fauna and an } \\
\text { increase in abundance of a limited number of epigean } \\
\text { (stygophilic) taxa - primarily Oligochaeta (Tubificidae). } \\
\text { Postonjna-Planina cave system - Increase in abundance } \\
\text { of epigean (stygophilic) taxa further within the cave and a } \\
\text { corresponding decline iof stygobitic taxa. }\end{array}$ \\
\hline Wood et al., 2002 & $\begin{array}{l}\text { Peak Cavern, } \\
\text { Derbyshire, UK }\end{array}$ & Paper pulp and peat & $\begin{array}{l}\text { Initial exclusion of all taxa and limited recovery of epigean } \\
\text { (stygophilic) taxa 9-months after detection of pollutant. }\end{array}$ \\
\hline
\end{tabular}



(1997-2003), and during the years when pollution occurred (1999 and 2002) within Peak 663 Cavern for affected and control sites.

\begin{tabular}{|c|c|c|c|c|c|c|}
\hline & \multirow{2}{*}{$\begin{array}{c}\text { SPEEDWELL } \\
\text { CAVERN } \\
1997-2003\end{array}$} & \multirow{2}{*}{$\begin{array}{c}\text { PEAK } \\
\text { CAVERN } \\
1997-2003\end{array}$} & \multicolumn{2}{|c|}{$\begin{array}{c}\text { PEAK } \\
\text { CAVERN } \\
\text { (Polluted sites) }\end{array}$} & \multicolumn{2}{|c|}{$\begin{array}{c}\text { PEAK } \\
\text { CAVERN } \\
\text { (Control sites) }\end{array}$} \\
\hline & & & 1999 & 2002 & 1999 & $2002^{1}$ \\
\hline \multicolumn{7}{|l|}{ PLANARIIDAE } \\
\hline Crenobia alpine & $\mathrm{X}$ & $\mathrm{X}$ & & & $\mathrm{X}$ & $\mathrm{X}$ \\
\hline \multirow{2}{*}{\multicolumn{7}{|c|}{ GASTROPODA }} \\
\hline & & & & & & \\
\hline Lymnaea peregra & & $\mathrm{X}^{*}$ & & & & \\
\hline \multicolumn{7}{|l|}{ BIVALVIA } \\
\hline Pisidium nitidum & & $\mathrm{X}$ & & & $\mathrm{X}$ & $\mathrm{X}$ \\
\hline Pisidium personatum & & $x$ & & & $\mathrm{x}$ & $x$ \\
\hline \multicolumn{7}{|l|}{ OLIGOCHAETA } \\
\hline Aporrectodea rosea & $\mathrm{X}$ & & & & $\mathrm{X}$ & $\mathrm{X}$ \\
\hline Enchytraeidae & $\mathrm{X}$ & $\mathrm{X}$ & & & $\mathrm{X}$ & $\mathrm{X}$ \\
\hline Limnodrilus hoffmeisteri & $\mathrm{X}$ & $\mathrm{X}$ & $\mathrm{X}$ & $\mathrm{X}$ & $\mathrm{X}$ & $\mathrm{X}$ \\
\hline Lumbriculus variegatus & $\mathrm{X}$ & $\mathrm{X}$ & & & $\mathrm{X}$ & $\mathrm{X}$ \\
\hline Lumbricus terrestris & $\mathrm{X}$ & $\mathrm{X}$ & $\mathrm{X}^{\mathrm{a}}$ & $\mathrm{X}$ & $\mathrm{X}$ & $\mathrm{X}$ \\
\hline Spirosperma ferox & $\mathrm{X}$ & $\mathrm{X}$ & & $\mathrm{X}$ & $\mathrm{X}$ & $\mathrm{X}$ \\
\hline Stylodrilus sp. & $\mathrm{X}$ & $\mathrm{X}$ & & & & \\
\hline Tubifex tubifex & $\mathrm{X}$ & $\mathrm{X}$ & $\mathrm{X}$ & $\mathrm{X}$ & $\mathrm{X}$ & $\mathrm{X}$ \\
\hline \multicolumn{7}{|l|}{ CRUSTACEA } \\
\hline \multicolumn{7}{|l|}{ CLADOCERA } \\
\hline Alona quadrangularis & $x$ & $x$ & & & $\mathrm{x}$ & $\mathrm{x}$ \\
\hline \multicolumn{7}{|l|}{ COPEPODA } \\
\hline \multicolumn{7}{|l|}{ HARPACTICOIDA } \\
\hline Atheyella crassa & & $\mathrm{X}$ & & & $\mathrm{X}$ & $\mathrm{X}$ \\
\hline Canthocamptus staphylinus & $x$ & $\mathrm{X}$ & & & $\mathrm{X}$ & $\mathrm{X}$ \\
\hline \multicolumn{7}{|l|}{ CYCLOPOIDA } \\
\hline Acanthocyclops venustus & $\mathrm{X}$ & $\mathrm{X}$ & & $\mathrm{X}$ & $\mathrm{X}$ & $\mathrm{X}$ \\
\hline Acanthocyclops vernalis & $\mathrm{X}$ & $\mathrm{X}$ & $\mathrm{X}^{\mathrm{b}}$ & $\mathrm{X}$ & $\mathrm{X}$ & $\mathrm{X}$ \\
\hline Diacyclops bicuspidatus bicuspidatus & & $\mathrm{X}$ & $\mathrm{X}^{\mathrm{b}}$ & $\mathrm{X}$ & $\mathrm{X}$ & $\mathrm{X}$ \\
\hline Diacyclops bicuspidatus lubbocki & & $\mathrm{X}$ & & & $\mathrm{X}$ & \\
\hline Eucyclops agilis & $\mathrm{x}$ & $\mathrm{X}$ & & & $\mathrm{X}$ & $\mathrm{X}$ \\
\hline Megacyclops gigas & $\mathrm{X}$ & $\mathrm{X}$ & & & $\mathrm{X}$ & $\mathrm{X}$ \\
\hline Megacyclops viridis & $\mathrm{x}$ & $\mathrm{X}$ & & $\mathrm{X}$ & $\mathrm{X}$ & $\mathrm{X}$ \\
\hline Paracyclops fimbriatus & & $\mathrm{X}$ & & & $\mathrm{X}$ & $\mathrm{X}$ \\
\hline \multicolumn{7}{|l|}{ GAMMARIDAE } \\
\hline Gammarus pulex & $\mathrm{X}$ & $\mathrm{X}$ & $\mathrm{X}^{\mathrm{b}}$ & $\mathrm{X}$ & $\mathrm{X}$ & $\mathrm{X}$ \\
\hline \multicolumn{7}{|l|}{ EPHEMEROPTERA } \\
\hline Baetis rhodani & $\mathrm{X}^{*}$ & & & & & \\
\hline \multicolumn{7}{|l|}{ COLEOPTERA } \\
\hline \multirow{2}{*}{\multicolumn{7}{|c|}{$\begin{array}{l}\text { DIPTERA } \\
\text { DIPT }\end{array}$}} \\
\hline & & & & & & \\
\hline \multicolumn{7}{|l|}{ Chironomidae } \\
\hline \multicolumn{7}{|l|}{ Chironominae } \\
\hline Polypedilum sp. & $\mathrm{x}$ & $\mathrm{X}$ & & $\mathrm{X}$ & $\mathrm{X}$ & $\mathrm{X}$ \\
\hline Orthocladiinae & & & & & & \\
\hline Brillia modesta & $\mathrm{X}$ & $\mathrm{X}$ & & & $\mathrm{X}$ & $\mathrm{X}$ \\
\hline Parametriocnemus stylatus & $\mathrm{X}$ & $\mathrm{X}$ & & $\mathrm{X}$ & $\mathrm{X}$ & $\mathrm{X}$ \\
\hline Rheocricotopus fuscipes & $\mathrm{X}$ & $\mathrm{X}$ & & $\mathrm{X}$ & $\mathrm{X}$ & $\mathrm{X}$ \\
\hline Tanypodinae & & & & & & \\
\hline Thienemannimyia gp. & $\mathrm{X}$ & $\mathrm{X}$ & & & & $\mathrm{X}$ \\
\hline Simuliidae & $\mathrm{X}^{*}$ & & & & & \\
\hline Thaumaleidae & & & & & & \\
\hline Thaumalea verralli & & $\mathrm{X}$ & & & $\mathrm{X}$ & $\mathrm{X}$ \\
\hline
\end{tabular}

664 Notes: ${ }^{1}$ Includes control site invaded by Gammarus pulex in 2002; * Indicates single specimens of 665 stygoxene (accidental) taxa recorded within the subterranean environment; ${ }^{a}$ All specimens of 666 Lumbricus terrestris recorded in the 5 months following the detection of pollution were dead and/or 
667 decomposing; ${ }^{\mathrm{b}}$ Taxa recorded for the first time 9-months after the detection of the pollution within 668 Peak Cavern.

669

670

671

672

673

674

675 
676 Table 3. Kruskal-Wallis pair-wise comparison between years for invertebrate community 677 parameters at sites within Peak Cavern affected by pollution (January 1997-December 2003):

678 a) abundance (individuals $\mathrm{m}^{-1}$ ); b) number of taxa; c) Shannon-Wiener diversity index; and d) 679 Berger-Parker dominance index. n.b. Site invaded by G. pulex not included in analysis of 6802002 and 2003. NS = not significant, $* \mathrm{P}<0.05$, ** $\mathrm{P}<0.01$ and $* * * \mathrm{P}<0.001$.

681

682

683

a)

\begin{tabular}{|c|c|c|c|c|c|c|}
\hline & 1997 & 1998 & 1999 & 2000 & 2001 & 2002 \\
\hline 1998 & NS & & & & & \\
\hline 1999 & $\star *$ & ** & & & & \\
\hline 2000 & NS & NS & * & & & \\
\hline 2001 & NS & NS & * & NS & & \\
\hline 2002 & $\star \star$ & ** & 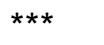 & $\star \star \star *$ & $\star \star \star$ & \\
\hline 2003 & NS & NS & * & NS & NS & $\star \star \star$ \\
\hline
\end{tabular}

684 b)

685

686

687

b)

\begin{tabular}{lllllll}
\hline & 1997 & 1998 & 1999 & 2000 & 2001 & 2002 \\
\hline 1998 & NS & & & & & \\
1999 & $*$ & $*$ & & & & \\
2000 & NS & NS & $*$ & & & \\
2001 & NS & NS & $*$ & NS & & \\
2002 & $* *$ & $*$ & $* \star *$ & $* *$ & $* *$ & \\
2003 & NS & NS & $*$ & NS & NS & $* *$ \\
\hline
\end{tabular}

c)

\begin{tabular}{lllllll}
\hline & 1997 & 1998 & 1999 & 2000 & 2001 & 2002 \\
\hline 1998 & NS & & & & & \\
1999 & $*$ & $*$ & & & & \\
2000 & NS & NS & $*$ & & & \\
2001 & NS & NS & $*$ & NS & & \\
2002 & $\star *$ & $*$ & $*$ & $* *$ & $* *$ & \\
2003 & NS & NS & $*$ & NS & NS & $* *$ \\
\hline
\end{tabular}

688 d)

689

\begin{tabular}{lllllll}
\hline & 1997 & 1998 & 1999 & 2000 & 2001 & 2002 \\
\hline 1998 & NS & & & & & \\
1999 & $*$ & $*$ & & & & \\
2000 & NS & NS & $*$ & & & \\
2001 & NS & NS & $*$ & NS & & \\
2002 & $* *$ & $*$ & $*$ & $* *$ & $* *$ & \\
2003 & NS & NS & $*$ & NS & NS & $* *$ \\
\hline
\end{tabular}

690

691

692

693 